\title{
Infrastruktura domowa i spożycie wybranych produktów żywnościowych wśród osób w wieku 65+ w świetle wyników badań własnych
}

\author{
Tomasz Zalega*
}

$W$ artykule zaprezentowano uwarunkowania zaspokojenia potrzeb $w$ zakresie mieszkania, wyposażenia w niektóre dobra trwatego użytkowania oraz produkty żywnościowe osób w wieku $65+$. Kluczowym celem autora jest ukazanie sytuacji mieszkaniowej, zadowolenia z miejsca zamieszkania $i$ warunków mieszkaniowych, a także przybliżenie infrastruktury domowej oraz spożycia produktów żywnościowych wśród seniorów. Opracowanie oparte jest na wynikach badań wtasnych przeprowadzonych wśród osób $w$ wieku 65 lat i więcej.

Slowa kluczowe: seniorzy, warunki mieszkaniowe, infrastruktura domowa, dobra trwałego użytku, produkty żywnościowe.

Nadesłany: 02.11.2016 | Zaakceptowany do druku: 15.12.2016

\section{Home Infrastructure and Consumption of Selected Food Products Among People Aged 65 + in the Light of the Results of the Author's Own Research}

The article presents the determinants underlying the satisfaction of needs as regards housing, some durable goods and food products among people aged 65+. Its key objective is to show seniors' housing situation, degree of contentment with place of residence and housing conditions, as well as to provide some insight into their home infrastructure and consumption of food products. The study is based on the results of the author's own research conducted among people aged 65 and older.

Keywords: seniors, housing conditions, home infrastructure, durable goods, food products.

Submitted: 02.11.2016 | Accepted: 15.12.2016

JEL: A12, D03, D18

\footnotetext{
Tomasz Zalega - dr hab., prof. UW, Katedra Gospodarki Narodowej, Wydział Zarządzania Uniwersytetu Warszawskiego.

Adres do korespondencji: Katedra Gospodarki Narodowej, Wydział Zarządzania, Uniwersytet Warszawski, ul. Szturmowa 1/3, 02-678 Warszawa; e-mail: tomasz.zalega@wp.pl.
} 


\section{Wprowadzenie}

Dla oceny struktury konsumpcji gospodarstw domowych podstawowe znaczenie, oprócz osiąganego dochodu przez poszczególnych jego członków, spożycia żywności, maja także warunki mieszkaniowe oraz wyposażenie mieszkania/domu w dobra trwałego użytku. Wywierają one bezpośredni wpływ na indywidualne postawy i zachowania konsumentów, a także w istotny sposób rzutują na zachowania rynkowe gospodarstw domowych, bez względu na relacje do sytuacji obiektywnej.

Kluczową cechą preferencji konsumpcyjnych gospodarstw domowych, a w efekcie i modelu konsumpcji, jest wyposażenie w dobra trwałego użytku, które tworzą tzw. infrastrukturę domową. Są one gromadzone i konsumowane $\mathrm{w}$ długim okresie, stanowiąc część trwałego majątku konsumpcyjnego. Ponadto świadczą o zamożności gospodarstwa domowego, zapewniają komfort życia i w pewnym stopniu niwelują wpływ okresowego obniżenia bieżących dochodów na stopień zaspokojenia potrzeb każdego z członków gospodarstwa. Stan posiadania gospodarstw domowych, będący swojego rodzaju wyznacznikiem dobrobytu społecznego, rzutuje w istotny sposób na zachowania nabywcze konsumentów. Generalnie, im wyższy stopień wyposażenia w dobra trwałego użytkowania, tym większa swoboda gospodarowania bieżącymi dochodami i tym wyższa średnia ocena poziomu życia. Ponadto w literaturze przedmiotu coraz częściej zwraca się uwage na to, że współczesne mieszkania/domy, dzięki wyposażeniu w dobra trwałego użytku, zaczynają spełniać wiele nowych funkcji społecznych, a mianowicie zaczynają zdaniem kanadyjskiego socjologa kultury Gillesa Pronovosta pełnić funkcje „miejsc konsumpcji sztuki", będących swoistą namiastką kin, teatrów, operetek, oper i filharmonii, a także miejsc z zakresu szeroko pojmowanej edukacji i rekreacji fizycznej (Pronovost, 2007). Spełnianie tych wszystkich funkcji w obrębie mieszkania jest możliwe dzięki posiadanemu sprzętowi informacyjnorozrywkowemu oraz szybkiemu rozwojowi i upowszechnieniu elektronicznych środków przekazu kulturowego takich, jak: telewizja satelitarna i kablowa, radio czy Internet. $\mathrm{W}$ ten sposób mieszkanie zaczyna w pewnym stopniu wyręczać niektóre instytucje społeczne, przyczyniając się tym samym do zmniejszenia przestrzeni życiowej współczesnego konsumenta, co z kolei rzutuje na jego zachowania nabywcze.

Dobra trwałego użytku pełnią trzy podstawowe funkcje: użytkową, wymienna i symboliczną. Funkcje użytkowe dóbr trwałego użytku służą bezpośrednio do zaspokojenia określonych potrzeb lub są środkiem umożliwiającym pośrednio zaspokojenie odczuwanych potrzeb. Z kolei funkcje wymienne dóbr trwałego użytku posiadają pewną wymienną wartość, np. w okresie niedoborów towarów na rynku służą jako przedmioty procesu wymiany lub stają się lokatą posiadanych nadwyżek pieniędzy. Natomiast funkcja symboliczna polega na tym, że niektóre dobra ze względu na swój walor rzadkości i oznaki zamożności stały się wymiarem dystynkcji społecznych, np. posiadanie domu w ekskluzywnej części miasta, różnego rodzaju urządzenia, w których zastosowano nowe technologie informatyczne itd. Obecnie większość dóbr utraciła funkcję symboliczną i częściowo funkcję wymienną. W sytuacji powszechnej dostępności dóbr trwałego użytku na rynku, dobra te w większości nie posiadają waloru rzadkości i oznak zamożności. Wyjątek stanowią dobra trwałego użytku zaliczane do tzw. dóbr veblenowskich, czyli dóbr, które związane są z konsumpcją ostentacyjną występująca najczęściej w gospodarstwach domowych wysokodochodowych i tych, które zaliczane są do tzw. elit ekonomicznych.

Rozwój technologii, który jest naturalną konsekwencją postępu technicznego, sprawia, że dostarczane są społeczeństwu nowe oraz bardziej zmodyfikowane dobra i usługi, które służą zaspokojeniu potrzeb w sposób skuteczniejszy, a także pozwalają na kreowanie nowych potrzeb. Odnosi się to głównie do urządzeń tzw. nowej generacji.

W artykule zaprezentowano uwarunkowania zaspokojenia potrzeb w zakresie mieszkania, wyposażenia w niektóre dobra trwałego użytkowania oraz produkty żywnościowe osób w wieku 65 lat i więcej. Jego kluczowym celem jest ukazanie sytuacji mieszkaniowej, zadowolenia z miejsca zamieszkania i warunków mieszkaniowych, a także przybliżenie infrastruktury domowej oraz spożycia produktów żywnościowych wśród seniorów.

Struktura opracowania jest następująca. Po krótkim wprowadzeniu, w pierwszej czę- 
ści tekstu skoncentrowano się na konceptualizacji badań oraz opisie próby i jej cech charakterystycznych. Następnie przeanalizowano sytuację mieszkaniową seniorów oraz ich zadowolenie $\mathrm{z}$ miejsca zamieszkania i warunków mieszkaniowych. W dalszej części opracowania, w sposób syntetyczny, skoncentrowano się na analizie wyposażenia osób w starszym wieku w wybrane dobra trwałego użytku oraz spożycia produktów żywnościowych. Ważniejsze wniosk kończą niniejszy artykuł.

\section{Konceptualizacja badań}

Materiał empiryczny zawarty w artykule pochodzi z badań bezpośrednich przeprowadzonych $\mathrm{w}$ formie wywiadu kwestionariuszowego na próbie 2537 gospodarstw domowych w latach 2014-2015 w dziesiecciu miastach Polski o zróżnicowanej liczbie ludności oraz wielkości. Zgodnie z przyjętymi założeniami badawczymi w próbie znalazły się osoby powyżej 65 . roku życia, które podejmowały suwerenne decyzje nabywcze na rynku. W doborze próby zastosowano procedurę doboru celowo-kwotowego. Przyjętymi w badaniu cechami (kwotami) były: płeć i wiek.

Badania zostały przeprowadzone wśród uczestników Uniwersytetu Trzeciego Wieku w państwowych uczelniach wyższych w: Warszawie, Krakowie, Łodzi, Poznaniu, Gdańsku, Katowicach, Lublinie, Białymstoku, Toruniu i we Wrocławiu, a także wśród członków kół parafialnych, w parafiach znajdujacych sie na terenie Archidiecezji: Warszawskiej, Krakowskiej, Łódzkiej, Białostockiej, Gdańskiej, Katowickiej, Lubelskiej, Poznańskiej, Wrocławskiej oraz Diecezji: Warszawsko-Praskiej i Toruńskiej.

\section{Dobór próby badawczej i jej charakterystyka}

Badania zachowań konsumenckich sa procesem niezwykle złożonym. Wynika to ze złożoności konsumpcji i zachowań nabywczych konsumentów w dziedzinie podejmowania decyzji konsumpcyjnych. W tego typu badaniach ważnym krokiem służącym do wyjaśnienia badanego zjawiska jest przyjęcie określonych wskaźników. Ma to istotne znaczenie, ponieważ wskaźnik służy do określenia pewnej cechy przedmiotu lub zjawiska pozostającej w takich związkach z inną cechą, że wystąpienie jej sygnalizuje obecność tej drugiej. Wskaźnikiem jest zmienna mierzalna, czyli dostępna empirycznie. W przypadku badania zachowań konsumenckich wskaźnikami wyjaśniającymi złożoność tego zjawiska sa wskaźniki demograficzne (płeć, wiek, miejsce zamieszkania, wielkość gospodarstwa domowego) oraz wskaźniki społeczno-ekonomiczne (wykształcenie, dochód).

W przeprowadzonym badaniu kobiety stanowiły $71 \%$, a jedynie co trzeci ankietowany był mężczyzną. W próbie wystąpiła wyraźna przewaga kobiet nad mężczyznami, zaś najliczniejszą grupę wiekową stanowiły osoby z przedziału wiekowego 65-74 lata ${ }^{1}$. Istotną zmienną w badaniu było także miejsce zamieszkania. W próbie respondentów, zgodnie z przyjętymi założeniami badawczymi, znalazły się osoby zamieszkujące najwiekssze miasta Polski.

Respondentom zadano także pytanie o poziom wykształcenia. W kwestionariuszu wywiadu przedstawiono cztery kategorie wykształcenia: podstawowe, zasadnicze zawodowe, średnie i wyższe. Najsilniej reprezentowane były osoby $\mathrm{z}$ wykształceniem średnim. Prawie $2 / 5$ ankietowanych legitymowało się tym poziomem wykształcenia. Co czwarty ankietowany ukończył studia wyższe, i podobny odsetek stanowiły osoby posiadające wykształcenie zasadnicze zawodowe. W badanej próbie najmniejszą grupę stanowiły osoby z wykształceniem podstawowym $(11,4 \%)$.

Blisko połowe badanych stanowiły osoby będące reprezentantami dwuosobowych gospodarstw domowych, natomiast niespełna $2 / 5$ ankietowanych reprezentowały gospodarstwa trzyosobowe. Z kolei co szósty respondent był przedstawicielem jednoosobowych gospodarstw domowych.

Największą grupę wśród respondentów stanowiły osoby, których miesięczny dochód per capita w gospodarstwie nie przekraczał 2000,00 zł. Dla co trzeciego ankietowanego dochód mieścił się w przedziale od 2001,00 do 3000,00 zł miesięcznie na 1 osobe w gospodarstwie domowym. $\mathrm{Z}$ kolei dla co czwartego badanego miesięczny rozporządzalny dochód na 1 osobę mieścił się $\mathrm{w}$ przedziale od 3001,00 do 4000,00 zł. Natomiast najmniejszą grupę wśród respondentów stanowiły gospodarstwa, w których dochód per capita wyniósł powyżej 4000,00 zł miesięcznie. 


\section{Sytuacja mieszkaniowa gospodarstw domowych osób w wieku $65+-$ wprowadzenie}

Mieszkanie i jego wyposażenie to ważny czynnik wpływający na realizację podstawowych potrzeb w gospodarstwach domowych. Materialne wyposażenie gospodarstwa domowego, to rzeczowy wymiar procesu konsumpcji, którego konkretnym wyrazem jest mieszkanie i jego wyposażenie. Mieszkanie wraz z wyposażeniem w trwałe ruchomości domowe stanowi materialno-przestrzenną ramę funkcjonowania gospodarstwa domowego, tworzy swoistą domową infrastrukturę konsumpcji (Wątorski, 1987, s. 14-15). Fakt posiadania mieszkania, jego standard oraz poziom wyposażenia w dobra trwałego użytkowania stanowi z jednej strony pochodną możliwości finansowych gospodarstwa domowego, $\mathrm{z}$ drugiej zaś powiązany jest $\mathrm{z}$ wykształceniem, wiekiem rodziny oraz okresem trwania gospodarstwa domowego (Zalega 2009, s. 92-93). Należy jednak pamiętać o tym, że od początku lat 90 . XX w. następuje polaryzacja warunków mieszkaniowych polskich gospodarstw domowych. Stosunkowo niskiemu poziomowi sytuacji mieszkaniowej przeciętnej rodziny towarzyszy duże i wielostronne zróżnicowanie, a skrajności standardowe $\mathrm{z}$ każdym rokiem pogłębiają się, co jest konsekwencją ogólnego społecznego i dochodowego rozwarstwienia, przy braku instrumentów regulujacych.

Mieszkanie jest określane jako przestrzeń, którą włada rodzina, dzięki której realizuje swoje podstawowe zadania i związane z nimi czynności, które uzyskuje w miarę możliwości, zgodnie z własnymi potrzebami, systemem wartości i preferencjami. Ponadto mieszkanie zaspokaja potrzeby podstawowe, bez czego niemożliwy jest pełny rozwój potrzeb wyższego rzędu. Lokalizacja mieszkania, jego wielkość i standard są bardzo często wyznacznikami statusu społecznego, określają w dużym stopniu przynależność grupową, wskazują na możliwości ekonomiczne, a także ukazuja gusta i preferencje właściciela. Posiadanie własnego mieszkania/ domu jest kluczowym warunkiem prawidłowego funkcjonowania każdego gospodarstwa domowego, ponieważ z jednej strony umożliwia realizację prawie wszystkich wykonywanych w jego obrębie czynności związanych z obsługą życia rodzinnego, z drugiej zaś stwarza możliwość gromadzenia majątku trwałego.

Standard mieszkania w zakresie jego lokalizacji i wielkości (powierzchnia, liczba pokoi), wyposażenie $\mathrm{w}$ zestaw instalacji techniczno-sanitarnych, użyty materiał budowlany, wewnętrzne rozplanowanie oraz stan techniczny są istotnymi czynnikami umożliwiającymi użytkowanie konkretnego mieszkania. Nowoczesne mieszkanie/dom staje się miejscem wypoczynku, regeneracji sił, czynnikiem sprzyjającym konsolidacji życia rodzinnego, więzi społecznych oraz materialną podstawą indywidualnego rozwoju członków społeczeństwa. Mieszkanie/dom staje się także uosobieniem indywidualnych dążeń i ambicji każdego człowieka, dając mu możliwość uzewnętrznienia własnego stylu życia. Ponadto, w mieszkaniu/domu realizowane są kluczowe funkcje rodziny i gospodarstwa domowego, $\mathrm{z}$ tego też względu powinno ono sprzyjać zarówno organizowaniu, jak i prawidłowemu wypełnianiu tak istotnych funkcji gospodarstwa domowego jak (Kusińska, 2009, s. 38): przygotowywanie i spożywanie posiłków, sen, rekreacja, wychowanie i nauka potomstwa, dokształcanie dorosłych członków gospodarstwa, hobby oraz kontakty towarzyskie.

\section{Warunki mieszkaniowe seniorów}

Standard mieszkania w zakresie jego wielkości (powierzchnia, liczba pokoi), wyposażenie w zestaw instalacji technicznosanitarnych, użyty materiał budowlany, wewnętrzne rozplanowanie i stan techniczny są istotnymi czynnikami umożliwiającymi użytkowanie konkretnego mieszkania (Żelazna, Kowalczuk i Mikuta, 2002, s. 116).

W przeprowadzonym badaniu przyjęto, że za mieszkanie wyposażone w wodociąg, ustęp, łazienkę itp. należy uznać mieszkanie, w obrębie którego znajdują się odpowiednie urządzenia. Nie jest wyposażone na przykład w wodociag mieszkanie, w którym kran z wodą znajduje się na ogólnie dostępnej klatce schodowej, poza obrębem mieszkania.

$\mathrm{Z}$ analizy warunków mieszkaniowych badanych gospodarstw domowych wynika, że w najlepiej w podstawowe instalacje wyposażone były ankietowane rodziny mieszkające w Warszawie, Poznaniu i Wrocławiu (tabela 1). 
Tabela 1. Wyposażenie mieszkań w podstawowe instalacje w gospodarstwach domowych osób w wieku $65+(w \%)$

\begin{tabular}{|l|c|c|c|c|c|c|}
\hline $\begin{array}{c}\text { Miejsce } \\
\text { zamieszkania }\end{array}$ & $\begin{array}{c}\text { Instalacje } \\
\text { wodno-kanali- } \\
\text { zacyjne }\end{array}$ & Ubikacja & Łazienka & przewodowy & $\begin{array}{c}\text { Centralne } \\
\text { ogrzewanie }\end{array}$ & $\begin{array}{c}\text { Z dostawą } \\
\text { ciepłej wody }\end{array}$ \\
\hline Ogółem & 98,6 & 95,7 & 91,8 & 84,6 & 85,9 & 63,4 \\
\hline Warszawa & 99,7 & 98,3 & 95,9 & 83,7 & 93,7 & 79,8 \\
\hline Kraków & 99,4 & 94,5 & 88,7 & 85,9 & 85,4 & 62,9 \\
\hline Łódź & 98,8 & 92,7 & 85,1 & 81,7 & 81,9 & 59,3 \\
\hline Poznań & 99,1 & 98,2 & 92,8 & 86,4 & 89,1 & 63,6 \\
\hline Wrocław & 98,6 & 97,8 & 94,8 & 90,3 & 87,6 & 70,7 \\
\hline Gdańsk & 99,0 & 97,2 & 96,3 & 82,4 & 87,2 & 63,1 \\
\hline Katowice & 97,7 & 96,2 & 94,2 & 84,2 & 84,9 & 62,5 \\
\hline Lublin & 98,2 & 93,3 & 89,1 & 84,7 & 80,7 & 53,9 \\
\hline Białystok & 97,5 & 92,9 & 90,3 & 79,6 & 80,3 & 58,5 \\
\hline Toruń & 98,4 & 96,4 & 91,3 & 86,7 & 88,2 & 59,7 \\
\hline
\end{tabular}

Źródło: badania własne.

Ponad 98\% badanych gospodarstw zamieszkiwało mieszkania wyposażone $\mathrm{w}$ wodociąg, $95,7 \%$ posiadało $\mathrm{w}$ domu ustęp spłukiwany wodą bieżącą, a 91,8\% posiadało $\mathrm{w}$ mieszkaniu łazienkę $\mathrm{z}$ wanna lub prysznicem. $\mathrm{Z}$ pozostałymi instalacjami było już trochę gorzej. Dość znaczna liczba mieszkań (zwłaszcza w Białymstoku i Łodzi) pozbawiona była gazu z sieci (odpowiednio: 20,4\% i 15,9\%). Ponad $14 \%$ badanych zamieszkiwało mieszkanie, w którym nie było centralnego ogrzewania (zbiorowego lub indywidualnego), zaś w przypadku 36\% badanych nie było dostawy ciepłej wody bieżącej do mieszkań.

Mieszkania badanych gospodarstw seniorów najczęściej posiadały centralne ogrzewanie indywidualne lub zbiorowe, zaś w przypadku prawie co siódmego gospodarstwa mieszkania były ogrzewane piecami na opał. Ten typ ogrzewania występował najczęściej w gospodarstwach domowych osób w wieku $65+$ zamieszkujących Białystok (19,7\%), Lublin (19,3\%) i Łódź $(18,1 \%)$. Z kolei ciepłej wody bieżącej najczęściej nie posiadały mieszkania seniorów zamieszkujących Lublin $(46,1 \%)$, Białystok (41,5\%), Łódź (40,7\%) i Toruń (40,3\%). Należy również nadmienić, że mieszkaniami bez ciepłej wody bieżącej dysponowali przeważnie seniorzy, których miesięczny dochód rozporządzalny na 1 osobę nie przekraczał 2000,00 zł, zaś badani legitymowali się wykształceniem podstawowym lub zasadniczym zawodowym.

Należy podkreślić, że brak wyposażenia mieszkania w lazienkę czy ustęp oznacza dziś bardzo niski standard mieszkania. Można więc stwierdzić, że ok. 6,25\% gospodarstw domowych seniorów zamieszkuje mieszkania, które w dzisiejszych czasach nie spełniają podstawowych wymogów stawianych współczesnym mieszkaniom.

$\mathrm{Z}$ przeprowadzonego badania wynika, że średnia wielkość powierzchni użytkowej mieszkania wyniosła 74,6 $\mathrm{m}^{2}$. Najmniejsze mieszkanie zarejestrowane w trakcie badania miało powierzchnię $31,75 \mathrm{~m}^{2}$, a największe - $149,87 \mathrm{~m}^{2}$. Przeciętne mieszkanie ankietowanego złożone było z 3,56 izb. Przecietna powierzchnia użytkowa zajmowana przez ankietowane gospodarstwa domowe na 1 osobę wynosiła $29,64 \mathrm{~m}^{2}$, zaś liczba osób przypadających na jedną izbę kształtowała się na poziomie 1,04 .

Najczęściej powierzchnia mieszkań ankietowanych mieściła się $\mathrm{w}$ przedziale od $57,8 \mathrm{~m}^{2}$ do ok. $66,9 \mathrm{~m}^{2}$. Można zatem stwierdzić, że mieszkania badanych gospodarstw domowych w niewielkim stopniu są pozbawione podstawowych urządzeń oraz posiadają zadowalającą powierzchnię użytkową.

Odnotowano istotną zależność między liczbą izb w mieszkaniu i powierzchnią użytkową zajmowanego mieszkania a takimi 
cechami respondentów jak: wiek, poziom wykształcenia, sytuacja ekonomiczna czy miejsce zamieszkania. Szczegółowe zestawienie prezentuje tabela 2 .

Tabela 2. Wybrane wskaźniki sytuacji mieszkanio wej badanych seniorów (w \%)

\begin{tabular}{|c|c|c|}
\hline Wyszczególnienie & 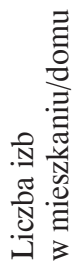 & 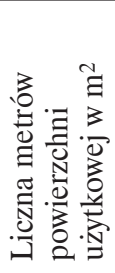 \\
\hline Ogółem & 3,56 & 74,6 \\
\hline $\begin{array}{l}\text { Wiek: } \\
\text { 65-74 lat } \\
\text { 75-84 lata } \\
\text { 85 lat i więcej }\end{array}$ & $\begin{array}{l}3,79 \\
3,63 \\
3,29\end{array}$ & $\begin{array}{l}79,2 \\
75,6 \\
69,0\end{array}$ \\
\hline $\begin{array}{l}\text { Wykształcenie: } \\
\text { podstawowe } \\
\text { zasadnicze zawodowe } \\
\text { średnie } \\
\text { wyższe }\end{array}$ & $\begin{array}{l}3,19 \\
3,58 \\
3,49 \\
3,98\end{array}$ & $\begin{array}{l}68,1 \\
75,3 \\
74,7 \\
80,3\end{array}$ \\
\hline $\begin{array}{l}\text { Dochód na } 1 \text { osobę: } \\
\text { do 2000,00 zł } \\
2001,00-3000,00 \mathrm{zl} \\
\text { 3001,00-4000,00 zł } \\
\text { powyżej 4000,00 zł }\end{array}$ & $\begin{array}{l}2,79 \\
3,68 \\
3,76 \\
4,01\end{array}$ & $\begin{array}{l}64,5 \\
75,2 \\
77,6 \\
81,1\end{array}$ \\
\hline $\begin{array}{l}\text { Miejsce zamieszkania: } \\
\text { Warszawa } \\
\text { Kraków } \\
\text { Łódź } \\
\text { Poznań } \\
\text { Wrocław } \\
\text { Gdańsk } \\
\text { Katowice } \\
\text { Lublin } \\
\text { Białystok } \\
\text { Toruń }\end{array}$ & $\begin{array}{l}3,57 \\
3,52 \\
3,46 \\
3,51 \\
3,64 \\
3,62 \\
3,27 \\
3,68 \\
3,72 \\
3,61\end{array}$ & $\begin{array}{l}73,2 \\
73,9 \\
72,6 \\
73,6 \\
75,6 \\
75,1 \\
71,3 \\
76,8 \\
79,2 \\
74,6\end{array}$ \\
\hline
\end{tabular}

Źródło: badania własne.

Z przeprowadzonych badań wynika, że najmniejsze mieszkania $\left(31,75-39,87 \mathrm{~m}^{2}\right)$ zarówno ze względu na liczbę izb, jak i powierzchnię użytkową, zajmowały gospodarstwa domowe, gdzie senior reprezentował grupę wiekową 75-84 lata. Natomiast największe mieszkania pozostawały w użytkowaniu seniorów z przedziału wiekowego
65-74 lata $\left(77,69-82,62 \mathrm{~m}^{2}\right)$. W kontekście uzyskanych wyników warto podać, że te gospodarstwa domowe były obciążone najwyższymi opłatami stałymi (zarówno za energię elektryczną i gaz, jak i za czynsz oraz inne opłaty sztywne).

W świetle przeprowadzonych analiz statystycznych okazało się, że grupa dochodowa, jaka reprezentowały badane gospodarstwa seniorów nie różnicowała istotnie ich warunków mieszkaniowych, co zwłaszcza dotyczyło liczby izb w mieszkaniu (wartość wskaźnika korelacji Pearsona $=0,029, \mathrm{p} \leq 0,01)$, a także wielkości powierzchni użytkowej mieszkania (wartość współczynnika korelacyjnego Pearsona $=0,067, \mathrm{p} \leq 0,01)$.

Interesującym spostrzeżeniem jest również to, że seniorzy legitymujący się wyższym wykształceniem zajmowali $\mathrm{z}$ reguły większe mieszkania $(4,26$ izby na mieszkanie i $84,8 \mathrm{~m}^{2}$ ) i, co jest w pełni zrozumiałe, w najwyższym stopniu obciążeni byli wszelkimi opłatami z tytułu jego użytkowania. Odnotowano także, że słuchacze UTW częściej niż seniorzy uczestniczący we wspólnotach parafialnych dysponowali większymi mieszkaniami.

Uwzględniając miejsce zamieszkania osób w wieku $65+$, można zauważyć, że im mniejsze miasto, tym większa liczba izb i powierzchnia użytkowa zajmowanego mieszkania. Wynika to przede wszystkim $\mathrm{z}$ tego, że mieszkanie w bloku było typowe dla mieszkańców największych miast (głównie Warszawy, Krakowa i Łodzi), natomiast zajmowanie domu jednorodzinnego wolno stojącego było częstsze wśród mieszkańców mniejszych miast takich jak Białystok czy Lublin. Należy również zaznaczyć, że im mniejsze pod względem liczby mieszkańców miasto reprezentowała osoba w wieku 65 lat i więcej, tym mniejsze były również obciążenia z tytułu czynszu i innych opłat sztywnych. Najmniejsze opłaty czynszowe deklarowali seniorzy mieszkający w Białymstoku i Lublinie.

\section{Zadowolenie $\mathrm{z}$ miejsca zamieszkania i warunków mieszkaniowych}

Istotnym elementem analizy warunków mieszkaniowych jest także ocena zadowolenia badanych seniorów z miejsca zamieszkania i z aktualnych warunków mieszkaniowych. 
Tabela 3. Stopień zadowolenia seniorów z miejsca zamieszkania ( $w$ \%)

\begin{tabular}{|l|c|c|}
\hline \multicolumn{1}{|c|}{ Wyszczególnienie } & $\begin{array}{c}\text { Liczba respondentów } \\
(\mathbf{N = 2 5 3 7 )}\end{array}$ & Udzial procentowy \\
\hline Jestem bardzo niezadowolony (ocena 1)* & 89 & 3,5 \\
\hline Jestem niezadowolony (ocena 2) & 540 & 21,3 \\
\hline Jestem średnio zadowolony (ocena 3) & 774 & 30,5 \\
\hline Jestem zadowolony (ocena 4) & 680 & 26,8 \\
\hline Jestem bardzo zadowolony (ocena 5) & 454 & 17,9 \\
\hline Średnia ocena w 5-stopniowej skali & - & 3,34 \\
\hline
\end{tabular}

* 1 - bardzo niezadowolony, 5 - bardzo zadowolony.

Źródło: badania własne.

Z przeprowadzonego badania wynika, że zaledwie co czwarty respondent nie był zadowolony z miejsca zamieszkania, zaś co piąty zadeklarował, że jest bardzo zadowolony (tabela 3 ).

Biorąc pod uwagę stopień zadowolenia badanych $\mathrm{z}$ miejsca zamieszkania, można dostrzec, że prawie co drugi senior $(44,5 \%$ wskazań) ocenił go na poziomie dobrym i bardzo dobrym, zaś na poziomie złym i bardzo złym zaledwie co czwarty z ankietowanych (24,8\% wskazań). Prawie co trzeci respondent (30,5\% wskazań) ocenił natomiast miejsce swojego zamieszkania na poziomie średnim. Wyniki badania wykazały, że osoby w wieku $65+$ aktywnie uczestniczące $\mathrm{w}$ kołach parafialnych częściej niż słuchacze UTW były zadowolone z miejsca zamieszkania.

Niewątpliwie dobrym uzupełnieniem oceny zadowolenia badanych $\mathrm{z}$ miejsca zamieszkania będą oceny poziomu zadowolenia z warunków mieszkaniowych, czyli z liczby pokoi i powierzchni mieszkania (tabela 4).
Oceny respondentów w zakresie zadowolenia $\mathrm{z}$ warunków mieszkaniowych sa nieco niższe aniżeli z miejsca zamieszkania. $\mathrm{Z}$ przeprowadzonego badania wynika, że co trzeci senior (31,7\% wskazań) nie był zadowolony ze swojej sytuacji mieszkaniowej, zaś co dziesiąty (12,1\% wskazań) deklarował wysokie zadowolenie zarówno z liczby pokoi, jak i powierzchni zajmowanego mieszkania/domu. Na podstawie analizy materiału badawczego można wnioskować, że słuchacze UTW (46,3\%) częściej niż uczestnicy wspólnot parafialnych $(34,1 \%)$ są zadowoleni z warunków mieszkaniowych.

Łączne opinie respondentów uwzględniajace zarówno zadowolenie $\mathrm{z}$ miejsca zamieszkania, jak i sytuacji mieszkaniowej, biorąc pod uwagę zmienne zależne, prezentuje tabela 5 .

Opinie respondentów na ten temat różnicował wiek (współczynnik korelacji Pearsona $r=-0,132, p=0,01)$. Najcześciej swoje niezadowolenie $\mathrm{z}$ warunków mieszkaniowych i miejsca zamieszkania

Tabela 4. Stopień zadowolenia seniorów z warunków mieszkaniowych (w \%)

\begin{tabular}{|l|c|c|}
\hline \multicolumn{1}{|c|}{ Wyszczególnienie } & $\begin{array}{c}\text { Liczba respondentów } \\
(\mathbf{N}=\mathbf{2 5 3 7})\end{array}$ & Udzial procentowy \\
\hline Jestem bardzo niezadowolony (ocena 1)* & 238 & 9,4 \\
\hline Jestem niezadowolony (ocena 2) & 566 & 22,3 \\
\hline Jestem średnio zadowolony (ocena 3) & 713 & 28,1 \\
\hline Jestem zadowolony (ocena 4) & 746 & 29,4 \\
\hline Jestem bardzo zadowolony (ocena 5) & 274 & 10,8 \\
\hline Średnia ocena w 5-stopniowej skali & - & 3,1 \\
\hline
\end{tabular}

* 1 - bardzo niezadowolony, 5 - bardzo zadowolony.

Źródło: badania własne. 
Tabela 5. Struktura gospodarstw domowych seniorów ze względu na stopień zadowolenia z charakteru miejsca zamieszkania i warunków mieszkaniowych (w \%)

\begin{tabular}{|c|c|c|c|c|c|}
\hline \multirow[t]{2}{*}{ Wyszczególnienie } & \multicolumn{5}{|c|}{$\begin{array}{c}\text { Procentowy udział ocen stopnia zadowolenia z sytuacji } \\
\text { mieszkaniowej i miejsca zamieszkania }\end{array}$} \\
\hline & "1" & "2" & "3" & "4" & "5" \\
\hline Ogółem & 6,5 & 21,8 & 29,3 & 28,1 & 14,3 \\
\hline $\begin{array}{l}\text { Wiek: } \\
\text { 65-74 lata } \\
\text { 75-84 lata } \\
\text { 85 lat i więcej }\end{array}$ & $\begin{array}{l}4,7 \\
7,2 \\
7,6\end{array}$ & $\begin{array}{l}21,2 \\
23,7 \\
20,5\end{array}$ & $\begin{array}{l}27,7 \\
30,4 \\
29,8\end{array}$ & $\begin{array}{l}30,3 \\
27,4 \\
26,6\end{array}$ & $\begin{array}{l}16,1 \\
11,3 \\
15,5\end{array}$ \\
\hline $\begin{array}{l}\text { Wykształcenie: } \\
\text { podstawowe } \\
\text { zasadnicze zawodowe } \\
\text { średnie } \\
\text { wyższe }\end{array}$ & $\begin{array}{l}4,5 \\
6,3 \\
6,8 \\
8,4\end{array}$ & $\begin{array}{l}24,7 \\
23,9 \\
20,2 \\
18,4\end{array}$ & $\begin{array}{l}31,6 \\
30,2 \\
28,7 \\
26,7\end{array}$ & $\begin{array}{l}25,3 \\
27,2 \\
29,8 \\
30,1\end{array}$ & $\begin{array}{l}13,9 \\
12,4 \\
14,5 \\
16,4\end{array}$ \\
\hline $\begin{array}{l}\text { Dochód na } 1 \text { osobę: } \\
\text { do 2000,00 zł } \\
\text { 2001,00-3000,00 zł } \\
\text { 3001,00-4000,00 zł } \\
\text { Powyżej 4000,00 zł }\end{array}$ & $\begin{array}{r}10,8 \\
7,3 \\
5,2 \\
2,7\end{array}$ & $\begin{array}{l}25,3 \\
22,6 \\
20,1 \\
19,2\end{array}$ & $\begin{array}{l}30,3 \\
29,8 \\
27,6 \\
29,5\end{array}$ & $\begin{array}{l}26,3 \\
28,0 \\
29,6 \\
28,5\end{array}$ & $\begin{array}{r}7,3 \\
12,3 \\
17,5 \\
20,1\end{array}$ \\
\hline $\begin{array}{l}\text { Miejsce zamieszkania: } \\
\text { Warszawa } \\
\text { Kraków } \\
\text { Lódź } \\
\text { Poznań } \\
\text { Wrocław } \\
\text { Gdańsk } \\
\text { Katowice } \\
\text { Lublin } \\
\text { Białystok } \\
\text { Toruń }\end{array}$ & $\begin{array}{l}7,1 \\
6,2 \\
8,7 \\
5,9 \\
6,0 \\
5,8 \\
7,5 \\
6,8 \\
5,4 \\
5,6\end{array}$ & $\begin{array}{l}22,3 \\
20,6 \\
24,0 \\
21,3 \\
21,9 \\
21,5 \\
22,3 \\
21,2 \\
21,5 \\
21,4\end{array}$ & $\begin{array}{l}30,4 \\
28,9 \\
28,8 \\
29,0 \\
27,9 \\
29,2 \\
30,8 \\
30,0 \\
29,1 \\
28,9\end{array}$ & $\begin{array}{l}27,6 \\
29,2 \\
26,8 \\
28,3 \\
27,7 \\
28,6 \\
26,9 \\
27,6 \\
28,3 \\
30,0\end{array}$ & $\begin{array}{l}12,6 \\
15,1 \\
11,7 \\
15,5 \\
16,5 \\
14,9 \\
12,5 \\
14,4 \\
15,7 \\
14,1\end{array}$ \\
\hline
\end{tabular}

Uwaga: Zastosowano pięciostopniową skalę ocen stopnia zadowolenia z sytuacji mieszkaniowej: 5 - bardzo zadowolony, 4 - zadowolony, 3 - średnio zadowolony, 2 - niezadowolony, 1 - bardzo niezadowolony.

Źródło: badania własne.

prezentowali respondenci należący do przedziału wiekowego 85 lat i więcej, najwięcej bowiem z nich wskazało ocenę „1" lub „2”. Tak niskie oceny świadczą o braku zadowolenia nie tylko z warunków mieszkaniowych, ale także z miejsca zamieszkania. Udział takich ocen w tej grupie wiekowej wyniósł $28,1 \%$. Z kolei w przedziale wiekowym 75-84 lata udział najniższych ocen wyniósł 30,9\%. Najmniej niezadowolonych z charakteru miejsca zamieszkania oraz warunków mieszkaniowych było wśród najmłodszych seniorów z grupy wiekowej 65-74 lata, spośród co czwarty wskazywał na swoje niezadowolenie w tym zakresie.
Wykształcenie okazało się kolejną zmienną istotnie statystycznie wpływającą na stopień zadowolenia respondentów z charakteru miejsca zamieszkania (współczynnik korelacji Spearmana $\mathrm{r}=-0,097$, $\mathrm{p}=0,01)$. Odnotowano, że im wyższy poziom wykształcenia seniorów, tym mniejsze zadowolenie $\mathrm{z}$ tego obszaru. Wśród osób z wyższym wykształceniem niezadowolenie $\mathrm{z}$ charakteru miejsca zamieszkania prezentował prawie co trzeci badany.

Zbliżony udział ocen najniższych (,1” i „2”) był również wśród osób w wieku 65 lat i więcej legitymujących się wykształceniem średnim. Najmniej niezadowolo- 
nych z charakteru zamieszkania było wśród osób z wykształceniem podstawowym. Prawie co trzeci senior mający najniższy poziom wykształcenia wskazywał niezadowolenie $\mathrm{z}$ miejsca zamieszkania oraz warunków mieszkalnych.

Opinie seniorów różnicowała ocena sytuacji finansowej. Generalnie, im korzystnie badany oceniał sytuację finansową w swoim gospodarstwie domowym, tym częściej deklarował większe zadowolenie $\mathrm{z}$ charakteru miejsca zamieszkania i warunków mieszkaniowych. Najwięcej ocen „4" i ,5" wskazywali badani dysponujący miesięcznym rozporządzalnym dochodem powyżej 4000,00 zł na 1 osobę. Prawie połowa badanych osiągających takie dochody bardzo wysoko oceniała stopień zadowolenia potrzeb w tym zakresie. Udział takich ocen wśród osób w wieku $65+$ z przedziału dochodowego 3001,00-4000,00 zł wyniósł 47,1\%. Najmniej zadowolonych zarówno z charakteru miejsca zamieszkania, jak i warunków mieszkaniowych było wśród gospodarstw domowych seniorów o najniższych miesięcznych dochodach (do 2000,00 zł na 1 osobę), spośród których co trzeci badany wskazywał na swoje zadowolenie w tym zakresie.

$\mathrm{Z}$ przeprowadzonego badania wynika, że miejsce zamieszkania było kolejną zmienną różnicującą badane gospodarstwa domowe seniorów pod względem stopnia zadowolenia zarówno z charakteru miejsca zamieszkania, jak i warunków mieszkaniowych. Zmienna ta w znacznie mniejszym stopniu różnicowała badaną populację aniżeli cechy demograficzne, takie jak: wykształcenie, wiek czy aktywność zawodowa. Można stwierdzić, że z im większego miasta pochodził respondent, tym wyższy był odsetek niezadowolonych w tym zakresie (współczynnik V-Cramera $=0,024$, przy $\mathrm{p} \leq 0,05)$. Najczęściej swoje niezadowolenie prezentowali respondenci mieszkający w Łodzi, Katowicach i Warszawie. Seniorzy z tych miast najczęściej wskazywali oceny najniższe (,1” i „2”), świadczące ewidentnie o braku zadowolenia w tym obszarze. Udział takich ocen w Łodzi wyniósł 32,7\%, Katowicach - 29,8\%, zaś w Warszawie 29,4\%. Zdecydowanie najmniej niezadowolonych z charakteru miejsca zamieszkania było wśród badanych mieszkających w Białymstoku, Krakowie i Poznaniu, spośód których odpowiednio: 26,9\%, 26,8\% i $27,2 \%$ wskazało najniższe oceny, a ponad
2/5 była zadowolona lub bardzo zadowolona, wskazując ocenę „4" i ,5”.

\section{Wyposażenie gospodarstw domowych seniorów w wybrane dobra trwałego użytku}

Kluczową cechą preferencji konsumpcyjnych gospodarstw domowych, a w efekcie i modelu konsumpcji jest wyposażenie w dobra trwałego użytku, które tworzą tzw. infrastrukture domową. Sa one gromadzone i konsumowane w długim okresie, a także świadcza o zamożności gospodarstwa domowego, zapewniają komfort życia i w pewnym stopniu niwelują wpływ okresowego obniżenia bieżących dochodów na stopień zaspokojenia potrzeb każdego z członków gospodarstwa. Stan posiadania gospodarstw domowych, będący swojego rodzaju wyznacznikiem dobrobytu społecznego, rzutuje w istotny sposób na zachowania nabywcze konsumentów. Generalnie, im wyższy stopień wyposażenia w dobra trwałego użytkowania, tym większa swoboda gospodarowania bieżącymi dochodami i tym wyższa średnia ocena poziomu życia (Zalega, 2012, s. 105-106).

Gospodarstwa domowe należące do określonej grupy społeczno-ekonomicznej często podkreślają swój stan posiadania, chcąc $\mathrm{w}$ ten sposób zbliżyć się do pewnego wzorca kształtowanego pod wpływem mody, upodobań, zwyczajów, pozycji itp. Zachowania takie stają się często czynnikiem zmieniającym zachowania konsumpcyjne społeczeństwa, unowocześniającym strukturę konsumpcji oraz strukturę wyposażenia gospodarstw domowych w dobra trwałego użytkowania (Słaby, 2006, s. 90). Ponadto zasoby domowych dóbr trwałego użytku wraz $\mathrm{z}$ mieszkaniem warunkuja szeroki zakres codziennych zachowań konsumpcyjnych wszystkich członków gospodarstw domowych składających się na wewnętrzną działalność gospodarstwa. Determinują również rozmiary czasu wolnego i sposób jego gospodarowania.

Niezależnie od obiektywnych korzyści znaczna część dóbr trwałego użytkowania znajdujących się w posiadaniu gospodarstwa domowego zaspokaja potrzeby wyższego rzędu i jako taka charakteryzuje standard życiowy ludności oraz stanowi wykładnik nowoczesności. Zdarza sie też czesto, chociaż nie zawsze słusznie, że dobra trwałego użytkowania traktowane są jako symbol pre- 
stiżu społecznego, nowej kultury materialnej i nowego stylu życia (Gutkowska, Ozimek i Laskowski, 2001, s. 103).

Szczególna rola dóbr trwałego użytku w działalności każdego gospodarstwa polega na usprawnieniu i mechanizacji prac domowych, wśród których wyróżnia się najczęściej (Kędzior, 1989, s. 4-6):

- sprzęty służące do przygotowywania potraw i przechowywania produktów spożywczych określane mianem sprzętów kuchennych, tj. chłodziarka, zamrażarka, roboty kuchenne, kuchenki mikrofalowe itd.;

- sprzęty służące do utrzymania ładu i czystości w mieszkaniu, do prania i konserwacji odzieży, określane mianem sprzętu ogólnogospodarczego, tj. pralki, wirówki elektryczne, odkurzacze, maszyny do szycia itd.;

- sprzęty zaspokajające potrzeby związane z domową rozrywką i wypoczynkiem, określane mianem elektronicznego sprzętu powszechnego użytku, tj. radia, magnetofony, telewizory, magnetowidy itd.

Biorąc pod uwagę rodzaj zaspokajanych potrzeb gospodarstwa domowego i poszczególnych jego członków, dobra trwałego użytku dzieli się na trzy podstawowe grupy (Zalega, 2010a):

- zmechanizowany sprzęt gospodarczy, czyli dobra bezpośrednio służące gospodarstwu domowemu, związane $\mathrm{z}$ potrzebą mechanizacji czynności domowych (np. przygotowanie i przechowywanie produktów żywnościowych - kuchenki, roboty kuchenne, chłodziarki, zamrażarki) oraz utrzymania czystości w mieszkaniu, prania i konserwacji odzieży, np. pralki automatyczne i wirnikowe, zmywarki, prasowalnice, roboty kuchenne, maszyny do szycia $\mathrm{i}$ inne;

- sprzęt informacyjno-rozrywkowy, czyli elektroniczny sprzęt powszechnego użytku, zaspokajający różnorodne potrzeby związane $\mathrm{z}$ domową rozrywką, wypoczynkiem lub nauką, który służy bezpośredniemu zaspokojeniu indywidualnych potrzeb członków gospodarstwa domowego, tj. telewizory, magnetowidy, odbiorniki radiowe, kamery wideo, komputery osobiste $\mathrm{i}$ inne;

- dobra związane z mobilnością, zaspokajające potrzeby w zakresie przemieszczania się, tj. rowery, motocykle samochody.
W celu zdiagnozowania sytuacji w zakresie wyposażenia gospodarstw domowych w sprzęt ułatwiający wykonywanie różnych czynności, wykorzystuje się trójstopniową skalę nasycenia:

- wysoki stopień nasycenia, który występuje w sytuacji, gdy dany sprzęt posiada ponad $80 \%$ gospodarstw domowych;

- średni stopień nasycenia, który występuje wówczas, gdy dany sprzęt posiada $50 \%$ do $80 \%$ gospodarstw domowych;

- niski stopień nasycenia, z którym mamy do czynienia wówczas, gdy dany sprzęt posiada mniej niż $50 \%$ populacji.

Powszechnie wykorzystywanymi identyfikatorami stopnia zaspokojenia potrzeb w zakresie dóbr trwałego użytku są: poziom i struktura wydatków $\mathrm{z}$ dochodów osobistych gospodarstw domowych oraz stan posiadania dóbr trwałego użytku. Wydatk na dobra i usługi konsumpcyjne określają finalną fazę zaspokojenia potrzeb w określonych warunkach wyboru na rynku. W przypadku dóbr trwałego użytku informują o realizacji bieżących zakupów dóbr i usług (Zalega, 2008, s. 186). Poprzez analizę struktury wydatków można określić miejsce dóbr trwałego użytku w procesie zaspokajania potrzeb.

Należy jednak mieć na uwadze, że stopień wyposażenia gospodarstw domowych w dobra trwałego użytku jest ściśle skorelowany z czynnikami społeczno-ekonomicznymi (tj. wiekiem, płcią, wykształceniem, cyklem życia rodziny, rodzajem mieszkania) oraz pozaekonomicznymi, jak: gusty, preferencje, naśladownictwo, zróżnicowane upodobania i inne (Zalega, 2010b, s. 172).

W świetle danych uzyskanych z przeprowadzonego badania można stwierdzić, że wyposażenie gospodarstw domowych seniorów w dobra trwałego użytku przez prawie co piątego respondenta zostało określone jako bardzo dobre, co trzeci badany ocenił je jako dobre. Stopień wyposażenia w przedmioty trwałego użytku przez co siódmą osobę wieku 65 lat i więcej określony został jako zły, zaś przez co dziesiątą jako bardzo zły. Natomiast co czwarty senior ocenił wyposażenie swojego mieszkania w dobra trwałego użytku na poziomie średnim. Ponadto wyższe oceny wyposażenia mieszkania w dobra trwałego użytku wskazywali seniorzy będący słuchaczami UTW $(56,3 \%)$ aniżeli osoby w starszym wieku uczestniczące w kołach parafialnych $(44,5 \%)$ (tabela 6).

Wydział Zarządzania UW ～DOI 10.7172/1733-9758.2016.22.7 
Tabela 6. Ocena wyposażenia gospodarstw domo wych seniorów w dobra trwałego użytku (w \%)

\begin{tabular}{|l|c|c|}
\hline $\begin{array}{c}\text { Ocena wyposażenia } \\
\text { gospodarstwa domowego } \\
\text { w dobra trwałego użytku }\end{array}$ & $\begin{array}{c}\text { Liczba } \\
\text { respon- } \\
\text { dentów } \\
(\mathbf{N = 2 5 3 7 )}\end{array}$ & $\begin{array}{c}\text { Udzial } \\
\text { procen- } \\
\text { towy }\end{array}$ \\
\hline Bardzo dobra & 503 & 19,8 \\
\hline Dobra & 776 & 30,6 \\
\hline Średnia (zadowalająca) & 637 & 25,1 \\
\hline Zła & 360 & 14,2 \\
\hline Bardzo zła & 261 & 10,3 \\
\hline
\end{tabular}

Źródło: badania własne.

\section{Zmechanizowany sprzęt gospodarczy}

W każdym gospodarstwie domowym istotną rolę odgrywa sprzęt związany z usprawnieniem i mechanizacją prac domowych. Wyposażenie badanych gospodarstw domowych w zmechanizowany sprzęt gospodarczy zaprezentowano w tabeli 7 . W odniesieniu do tego rodzaju dóbr trwałego użytku odsetek seniorów wskazujący wysokie ich nasycenie był zbliżony zarówno wśród słuchaczy UTW, jak i uczestniczących we wspólnotach parafialnych.
Z przeprowadzonego badania wynika, że stan posiadania zmechanizowanego sprzętu w gospodarstwach seniorów oraz stopień ich upowszechnienia był zróżnicowany. Wśród zmechanizowanego sprzętu gospodarczego $\mathrm{w}$ badanych rodzinach wysoki stopień nasycenia dotyczył pralek automatycznych (100,0\% wskazań) i chłodziarek (100,0\% wskazań) i odkurzaczy elektrycznych $(99,3 \%)$, a średni stopień nasycenia - robotów kuchennych (53,1\% wskazań) i kuchenek mikrofalowych $(49,5,8 \%$ wskazań). Spośród badanego sprzętu zmechanizowanego do najrzadziej występujących w gospodarstwach domowych zaliczyć należy zmywarkę do naczyń $(11,7 \%$ wskazań) oraz kuchenkę elektryczną z płytą ceramiczną (5,5\% wskazań).

\section{Sprzęt informacyjno-rozrywkowy i mobilny}

Oprócz zmechanizowanego sprzętu gospodarczego ważną rolę w gospodarstwie domowym odgrywa także sprzęt związany z rozrywka i wypoczynkiem w domu (tzw. sprzęt informacyjno-rozrywkowy) oraz sprzęt związany z przemieszczaniem się, komunikacją indywidualną (tzw. sprzęt mobilny).

Analiza stanu posiadania poszczególnych sprzętów informacyjno-rozrywkowych

Tabela 7. Wyposażenie gospodarstw domowych seniorów w zmechanizowany sprzęt gospodarczy (w \%)

\begin{tabular}{|c|c|c|c|c|c|c|c|c|c|c|}
\hline \multirow[b]{2}{*}{ Wyszczególnienie } & \multicolumn{10}{|c|}{ Miejsce zamieszkania } \\
\hline & 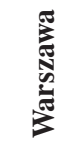 & 言 & 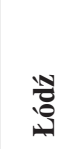 & 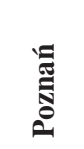 & $\frac{\vec{t}}{\bar{d}}$ & 造 & 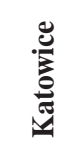 & 壬 & 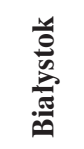 & $\stackrel{\Xi}{\varrho}$ \\
\hline $\begin{array}{l}\text { Pralka i wirówka } \\
\text { elektryczna lub automat } \\
\text { pralniczy }\end{array}$ & 100,0 & 100,0 & 100,0 & 100,0 & 100,0 & 100,0 & 100,0 & 100,0 & 100,0 & 100,0 \\
\hline Odkurzacz elektryczny & 98,3 & 99,1 & 96,7 & 99,5 & 99,8 & 100,0 & 99,8 & 99,8 & 99,6 & 100,0 \\
\hline $\begin{array}{l}\text { Chłodziarka lub } \\
\text { zamrażarka }\end{array}$ & 100,0 & 100,0 & 100,0 & 100,0 & 100,0 & 100,0 & 100,0 & 100,0 & 100,0 & 100,0 \\
\hline $\begin{array}{l}\text { Kuchenka elektryczna } \\
\text { z płytą ceramiczną }\end{array}$ & 9,3 & 7,2 & 3,8 & 5,6 & 4,2 & 3,9 & 4,2 & 4,0 & 3,9 & 4,8 \\
\hline Kuchenka mikrofalowa & 53,6 & 54,2 & 50,8 & 60,1 & 52,1 & 47,3 & 52,1 & 37,6 & 39,2 & 48,1 \\
\hline Robot kuchenny & 59,6 & 56,1 & 49,8 & 52,3 & 54,0 & 53,6 & 56,4 & 48,3 & 49,1 & 51,2 \\
\hline Zmywarka do naczyń & 13,4 & 11,8 & 10,7 & 13,1 & 12,5 & 10,9 & 11,2 & 10,8 & 11,1 & 12,4 \\
\hline
\end{tabular}

Źródło: badania własne. 
wskazuje na niższy stopień ich upowszechnienia niż zmechanizowanych sprzętów gospodarczych (tabela 8).

O wysokim poziomie nasycenia można mówić tylko w odniesieniu do odbiorników telewizyjnych (100,0\% wskazań) i telefonów komórkowych (94,8\% wskazań). Wśród posiadaczy odbiorników telewizyjnych prawie co trzeci ankietowany posiadał telewizor LCD plazmę lub LED. Średni poziom nasycenia można odnotować w przypadku telefonów stacjonarnych (60,5\% wskazań), komputerów osobistych (44,4\% wskazań) oraz urządzeń do odbioru telewizji satelitarnej (59,8\% wskazań). Na poziomie niskim badane gospodarstwa domowe wyposażone były w odtwarzacze DVD $(29,0 \%$ wskazań), magnetowidy (odtwarzacze) $(24,3 \%$ wskazań) i cyfrowe aparaty fotograficzne (24,2\% wskazań). Natomiast na bardzo niskim poziomie gospodarstwa domowe seniorów były wyposażone w odtwarzacze MP3 (3,2\% wskazań), kamer wideo (3,4\% wskazań), odtwarzaczy płyt kompaktowych (4,0\% wskazań) oraz zestawy kina domowego ( $6,4 \%$ wskazań).

$\mathrm{Z}$ przeprowadzonego badania wynika, że słuchacze UTW częściej niż seniorzy uczestniczący we wspólnotach parafialnych wskazywali na wysoki poziom nasycenia w większość dóbr zaliczanych do sprzętu informacyjno-rozrywkowego.

Przełom XX i XXI wieku to pojawienie się i stopniowe upowszechnianie wśród gospodarstw domowych takich dóbr i usług jak: komputer osobisty, telefon komórkowy czy Internet. W początkowym okresie lat $90 . \mathrm{XX}$ wieku komputery były dobrem stosunkowo drogim dla wielu indywidualnych użytkowników, zaś korzystanie z komputera wymagało określonych umiejętności. Stąd też wyposażenie gospodarstw domo-

Tabela 8. Wyposażenie gospodarstw domowych seniorów w sprzęt informacyjno-rozrywkowy (w \%)

\begin{tabular}{|c|c|c|c|c|c|c|c|c|c|c|}
\hline \multirow[b]{2}{*}{ Wyszczególnienie } & \multicolumn{10}{|c|}{ Miejsce zamieszkania } \\
\hline & 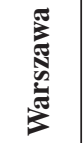 & 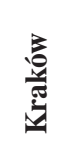 & 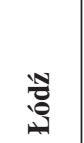 & 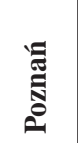 & 宽 & 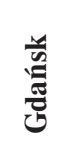 & لِّ & 哭 & 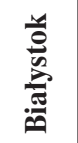 & 当 \\
\hline Odbiornik telewizyjny & 100,0 & 100,0 & 100,0 & 100,0 & 100,0 & 100,0 & 100,0 & 100,0 & 100,0 & 100,0 \\
\hline $\begin{array}{l}\text { Urządzenie do odbioru TV } \\
\text { satelitarnej lub kablowej }\end{array}$ & 67,3 & 62,1 & 54,3 & 59,2 & 61,7 & 64,8 & 61,7 & 55,3 & 52,7 & 58,9 \\
\hline Zestaw kina domowego & 7,3 & 6,8 & 6,8 & 7,2 & 7,5 & 6,9 & 7,8 & 4,3 & 4,0 & 5,1 \\
\hline Wieża stereofoniczna & 20,1 & 17,9 & 15,8 & 16,2 & 18,3 & 14,3 & 19,1 & 10,8 & 11,3 & 12,5 \\
\hline $\begin{array}{l}\text { Radio lub radiomagnetofon } \\
\text { z odtwarzaczem CD }\end{array}$ & 11,8 & 12,4 & 12,8 & 14,0 & 13,2 & 9,7 & 8,9 & 10,7 & 11,2 & 10,6 \\
\hline Odtwarzacz MP3 & 3,6 & 4,1 & 3,7 & 2,9 & 3,1 & 2,8 & 3,5 & 2,9 & 2,8 & 3,0 \\
\hline $\begin{array}{l}\text { Odtwarzacz płyt } \\
\text { kompaktowych }\end{array}$ & 4,1 & 3,9 & 5,0 & 4,3 & 3,6 & 3,8 & 4,0 & 3,7 & 3,5 & 3,9 \\
\hline Magnetowid/odtwarzacz & 15,3 & 13,6 & 13,5 & 12,8 & 12,3 & 11,9 & 12,8 & 14,9 & 15,1 & 13,5 \\
\hline Odtwarzacz DVD & 29,6 & 26,9 & 30,4 & 25,4 & 27,8 & 27,6 & 32,1 & 29,1 & 31,2 & 29,1 \\
\hline Kamera wideo & 3,4 & 2,9 & 3,1 & 3,0 & 2,7 & 4,1 & 3,9 & 4,0 & 2,7 & 3,8 \\
\hline $\begin{array}{l}\text { Cyfrowy aparat } \\
\text { fotograficzny }\end{array}$ & 26,1 & 25,8 & 24,1 & 23,8 & 22,7 & 23,6 & 26,3 & 21,9 & 23,6 & 24,1 \\
\hline $\begin{array}{l}\text { Komputer z dostępem do } \\
\text { Internetu }\end{array}$ & 51,2 & 43,6 & 39,2 & 43,1 & 42,8 & 45,6 & 47,7 & 42,9 & 41,5 & 46,8 \\
\hline Drukarka & 12,6 & 11,8 & 10,4 & 11,6 & 13,0 & 12,4 & 11,2 & 10,6 & 11,1 & 10,8 \\
\hline Telefon stacjonarny & 60,8 & 61,3 & 62,0 & 59,4 & 56,8 & 60,1 & 62,3 & 59,8 & 60,7 & 61,3 \\
\hline Telefon komórkowy & 96,2 & 95,7 & 93,6 & 96,8 & 95,9 & 95,3 & 96,0 & 93,3 & 92,8 & 93,7 \\
\hline
\end{tabular}

Źródło: badania własne. 
wych z osobami w tym okresie było śladowe. W ciągu niespełna dwóch dekad wzrosła użyteczność komputera i jego popularność, a także rozwinęło się przyjazne oprogramowanie użytkowe. W efekcie komputer (zwłaszcza przenośny) stał się dla wielu gospodarstw domowych podstawowym narzędziem nie tylko usprawniającym naukę i pracę czy komunikację, lecz także ułatwiającym znalezienie samej pracy, też dzięki usługom internetowym. Wszystko to spowodowało, że nastąpiła znaczna poprawa wyposażenia gospodarstw domowych w komputery osobiste (laptopy). W badanych gospodarstwach domowych komputer $\mathrm{z}$ dostępem do Internetu miało $44,4 \%$ badanych. Należy jednak pamiętać o tym, że posiadanie komputera jest ściśle skorelowane z osiąganym dochodem i zamożnością gospodarstwa domowego. Również usługa internetowa $\mathrm{w}$ przeciagu ostatnich lat stała się dostępna na szerszą skalę, czego konsekwencją jest dostrzegalny wzrost wyposażenia gospodarstw domowych w komputery $\mathrm{z}$ dostępem do Internetu. $\mathrm{Z}$ przeprowadzonych badań wynika, że dostęp do Internetu posiadał prawie co drugi senior.

Należy również pamiętać o tym, że w dzisiejszych czasach odbiornik TV to nie tylko programy telewizyjne, ale także baza zdjęć i filmów oraz realna alternatywa dla komputera (zwłaszcza stacjonarnego). Zjawisko to będzie nabierało na sile w najbliższej przyszłości, wraz z upowszechnieniem sie zaawansowanych technologicznie telewizorów określanych mianem OLED (Organic Light-Emitting Diode), nazywanych przez znawców tematu inteligentnymi telewizorami (bez pilota i z Internetem) i „zabójcami LCD i plazmy”. Telewizory te posiadają grubość ekranu nieprzekraczającą $4 \mathrm{~mm}$ oraz 4-kolorowe piksele mające za zadanie poprawić jakość wyświetlanego obrazu, a także dające niemal nieograniczony kąt widzenia. Ponadto telewizory OLED oferują nieskończony współczynnik kontrastu oraz szybkość odświeżania na poziome 0,02 milisekundy (czyli niemal 100 razy szybciej niż w telewizorach LCD).

Dobrem, którego popularność permanentnie wrasta we współczesnym świecie, $\mathrm{w}$ tempie zbliżonym do Internetu, i podobnie wpływającym na styl życia ludzi, jest telefon komórkowy. Znalazło to swoje odbicie w poprawie wyposażenia gospodarstw domowych w to urządzenie i to na przestrzeni kilku lat. W kontekście przeprowadzonych badań można wnioskować, że telefon komórkowy posiadało aż $94,8 \%$.

Analizując grupę dóbr trwałego użytku związaną $\mathrm{z}$ zaspokojeniem potrzeb w zakresie przemieszczania się, można zaobserwować średni stopień nasycenia w rowery i samochody osobowe. Posiadało je odpowiednio 48,0\% i 47,6\% seniorów (tabela 9). Badane gospodarstwa domowe osób w wieku $65+\mathrm{w}$ mniejszym stopniu dysponowały pojazdami jednośladowymi (motocykle, skutery, motorowery) $(2,1 \%$ wskazań). Lepiej w mobilne dobra trwałego użytku byli wyposażeni słuchacze UTW niż seniorzy uczestniczący we wspólnotach parafialnych. $\mathrm{Ci}$ pierwsi posiadali więcej rowerów i motorowerów, natomiast drudzy częściej byli posiadaczami samochodów osobowych.

Z przeprowadzonych badań wynika, że wyposażenie gospodarstw domowych w dobra trwałego użytku ulega istotnej poprawie ilościowej i jakościowej, a co za tym idzie, unowocześnieniu struktury posiadanych zasobów. Praktycznie zniknęły: telewizor czarno-biały, odbiornik radiowy monofoniczny, magnetofon czy gramofon

Tabela 9. Wyposażenie gospodarstw domowych osób w wieku 65+ w mobilne dobra trwałego użytku (w \%)

\begin{tabular}{|c|c|c|c|c|c|c|c|c|c|c|}
\hline \multirow[b]{2}{*}{ Wyszczególnienie } & \multicolumn{10}{|c|}{ Miejsce zamieszkania } \\
\hline & 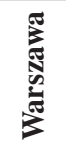 & 总 & 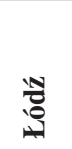 & 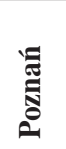 & $\frac{\vec{t}}{d !}$ & 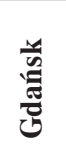 & & 恶 & $\frac{\frac{y}{0}}{\frac{0}{n}}$ & 哭 \\
\hline Rowery (bez dziecięcego) & 42,8 & 43,9 & 46,3 & 45,9 & 48,1 & 49,2 & 46,3 & 54,9 & 55,6 & 47,3 \\
\hline Motocykl, skuter, motorower & 2,3 & 1,9 & 1,7 & 1,8 & 2,1 & 2,3 & 2,0 & 2,6 & 2,4 & 1,9 \\
\hline Samochód osobowy & 49,3 & 47,6 & 42,9 & 46,8 & 47,5 & 47,3 & 48.2 & 49.6 & 51,2 & 46,1 \\
\hline
\end{tabular}

Źródło: badania własne. 
i maszyny do pisania. W ich miejsce weszły i szybko zostały zaakceptowane nowe dobra. Szczególnie dużo nowości pojawiło się w dziedzinie teleinformatyki; dotyczy to zwłaszcza urządzeń do odbioru telewizji satelitarnej i kablowej, sprzętu hi-fi, komputerów osobistych, Internetu czy telefonów komórkowych. Należy w tym miejscu zaznaczyć, że brak niektórych dóbr trwałego użytku w badanych gospodarstwach domowych seniorów może wynikać nie tyle z braku możliwości finansowych, ile z niechęci do ich posiadania.

\section{Poziom zaspokojenia potrzeb osób w wieku 65 + w dobra trwałego użytku}

Poziom zaspokojenia potrzeb w zakresie dóbr trwałego użytku jest silnie skorelowany z poziomem zamożności gospodarstw domowych. Dobra trwałego użytku, będące w posiadaniu badanych gospodarstw seniorów w różnym stopniu, zaspokajały ich potrzeby (tabela 10).

Z przeprowadzonego badania wynika, że ponad $64 \%$ gospodarstw domowych senio-

Tabela 10. Poziom zaspokojenia potrzeb w gospodarstw domowych seniorów w zakresie wybranych dóbr trwałego użytku (w \% wskazań)

\begin{tabular}{|l|c|c|c|}
\hline \multirow{2}{*}{\multicolumn{1}{|c|}{ Rodzaj asortymentu }} & \multicolumn{3}{c|}{ Poziom zaspokojenia potrzeb } \\
\cline { 2 - 4 } & $\begin{array}{c}\text { calkowicie } \\
\text { zaspokojone }\end{array}$ & $\begin{array}{c}\text { średnio } \\
\text { zaspokojone }\end{array}$ & niezaspokojone \\
\hline Pralka i wirówka elektryczna lub automat pralniczy & 100,0 & - & - \\
\hline Odkurzacz elektryczny & 98,5 & 1,5 & - \\
\hline Chłodziarka lub zamrażarka & 100,0 & - & - \\
\hline Kuchenka elektryczna z płyta ceramiczną & 65,4 & 15,3 & 19,3 \\
\hline Kuchenka mikrofalowa & 63,8 & 23,5 & 12,7 \\
\hline Robot kuchenny & 63,6 & 21,8 & 14,6 \\
\hline Zmywarka do naczyń & 21,2 & 48,3 & 30,5 \\
\hline Odbiornik telewizyjny & 100,0 & - & - \\
\hline Urządzenie do odbioru TV satelitarnej lub kablowej & 69,2 & 20,4 & 10,4 \\
\hline Zestaw kina domowego & 59,3 & 29,8 & 10,9 \\
\hline Wieża stereofoniczna & 35,4 & 27,3 & 37,3 \\
\hline Radio lub radiomagnetofon z odtwarzaczem CD & 58,3 & 25,2 & 16,5 \\
\hline Odtwarzacz MP3 & 48,9 & 36,2 & 14,9 \\
\hline Odtwarzacz płyt kompaktowych & 67,8 & 21,4 & 10,8 \\
\hline Magnetowid/odtwarzacz & 52,1 & 23,6 & 24,3 \\
\hline Odtwarzacz DVD & 61,7 & 19,8 & 18,5 \\
\hline Kamera wideo & 49,6 & 37,2 & 13,2 \\
\hline Cyfrowy aparat fotograficzny & 59,3 & 26,1 & 14,6 \\
\hline Komputer z dostępem do Internetu & 61,3 & 24,4 & 14,3 \\
\hline Drukarka & 50,6 & 29,3 & 20,1 \\
\hline Telefon stacjonarny & 69,3 & 25,1 & 5,6 \\
\hline Telefon komórkowy & 61,8 & 12,4 & 25,8 \\
\hline Rowery (bez dziecięcego) & 56,3 & 24,8 & 18,9 \\
\hline Motocykl, skuter, motorower & & 21,7 & 37,1 \\
\hline Samochód osobowy & & -1 \\
\hline
\end{tabular}

Źródło: badania własne. 
rów oceniło, że ma całkowicie zaspokojone potrzeby w zakresie dóbr trwałego użytku, co czwarty senior średnio ocenił poziom zaspokojonych potrzeb w tym zakresie, zaś prawie co siódmy badany uznał, że są one niezaspokojone.

W kontekście uzyskanych wyników można stwierdzić, że badane gospodarstwa domowe osób w wieku $65+$ są coraz lepiej wyposażone zarówno w sprzęt zmechanizowany, informacyjno-rozrywkowy, jak i sprzęty związane $\mathrm{z}$ mobilnością. Ma to niewątpliwie swoje przełożenie na poziom zaspokojenia potrzeb w zakresie dóbr trwałego użytku. Wyniki badań wskazują, że seniorzy uczestniczący aktywnie w zajęciach organizowanych przez UTW, częście niż badani uczestniczący we wspólnotach parafialnych, lepiej oceniają poziom zaspokojenia swoich potrzeb w dobra trwałego użytku.

\section{Spożycie wybranych produktów żywnościowych}

Warunkiem sine qua non prawidłowego funkcjonowania organizmu człowieka jest spożywanie żywności, dlatego też żywność należy do tej grupy produktów, która musi być obecna w konsumpcji człowieka, zaspokaja bowiem potrzeby wiscerogenne. Należy jednak zaznaczyć, że żywność nie posiada substytutów, a w hierarchii potrzeb, bez względu na sytuację dochodowa gospodarstwa domowego, zawsze będzie miała priorytetowe znaczenie, choć nie musi to oznaczać dominacji w strukturze spożycia. W przypadku pogarszania się sytuacji dochodowej gospodarstwa domowe w pierwszej kolejności chronią potrzeby podstawowe (niższego rzędu), w tym żywnościowe (efekt zapadki).

Potrzeby żywnościowe, zgodnie z kluczowymi teoriami i koncepcjami hierarchizacji potrzeb ludzkich, zaproponowanymi m.in. przez A.H. Maslowa (1954), C.P. Alderfera (1972), D.C. McClellanda (1975) czy M. Max-Neefa (1991), należa do podstawowych potrzeb fizjologicznych człowieka i uważane są za najważniejsze potrzeby każdej jednostki, których spełnienie warunkuje rozwój dalszych potrzeb.

Żywność konsumowana w gospodarstwach domowych pochodzi z trzech podstawowych źródeł. Po pierwsze, może ona pochodzić z własnego gospodarstwa lub działki, co w literaturze tematycznej okre- ślane jest mianem samozaopatrzenia lub spożyciem naturalnym. Owa autokonsumpcja jest jednym z kluczowych czynników wpływających na zachowania żywnościowe w gospodarstwach domowych, a zwłaszcza rolników i pracowników użytkujących gospodarstwo rolne, natomiast $\mathrm{w}$ innych grupach gospodarstw ma niewielkie znaczenie (Gutkowska, Ozimek i Laskowski, 2001, s. 116). Kolejnym ważnym źródłem zaspokajania potrzeb żywnościowych ludności są zakupy rynkowe, zwane także spożyciem rynkowym lub towarowym, które są finansowane $\mathrm{z}$ dochodów osobistych ludności i dotyczą jedynie tych zakupów żywności, które są dokonywane przez konsumentów na rynku zorganizowanym. Trzecim możliwym sposobem pozyskiwania żywności jest spożycie społeczne, zwane również spożyciem zbiorowym, które jest finansowane przez państwo. Srodki na ten cel pochodzą $\mathrm{z}$ budżetu centralnego lub zasobów finansowych władz lokalnych. Zwykle pomoc ta jest bezpłatna lub odpłatna częściowo.

Wraz z rozwojem gospodarczym kraju istotna cecha przemian w źródłach pozyskiwania żywności staje się przechodzenie od samozaopatrzenia w żywność do częstszych zakupów na rynku. Zmiany, jakie można zaobserwować w tym zakresie obejmują cechy zarówno ilościowe, jak i jakościowe, wynikające głównie z modernizacji zakładów produkujących żywność, które systematycznie udoskonalają swoje produkty oraz poszerzaja ich asortyment. W literaturze przedmiotu proces odchodzenia od spożycia naturalnego określany jest denaturalizacją spożycia. Wzbogacanie rynku w coraz bardziej zróżnicowane produkty żywnościowe przyczynia się do permanentnego zmniejszenia samozaopatrzenia na rzecz zakupów rynkowych (Zalega, 2011).

Konsument, będąc suwerennym uczestnikiem rynku, sam kształtuje poziom i strukture wydatków na dobra i usługi żywnościowe, które są efektem realizacji odczuwanych potrzeb, aspiracji i możliwości finansowych. Przemiany wydatków na żywność znajdują z kolei odbicie w ilościowym spożyciu produktów żywnościowych przez gospodarstwa domowe (tabela 11).

Poziom spożycia większości artykułów żywnościowych zależy w dużym stopniu od dochodów seniorów. Wraz ze wzrostem poziomu zamożności gospodarstw domowych w wieku $65+$ rośnie poziom spożycia niektórych artykułów żywnościowych. 
Tabela 11. Przeciętne miesięczne spożycie produktów żywnościowych na 1 osobę $w$ gospodarstw domowych osób w wieku 65+

\begin{tabular}{|c|c|c|c|c|c|c|c|c|c|c|c|}
\hline \multirow[b]{2}{*}{ Artykuły żywnościowe } & \multirow[b]{2}{*}{ 离 } & \multicolumn{10}{|c|}{ Miejsce zamieszkania } \\
\hline & & 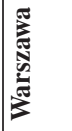 & 言 & 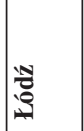 & 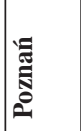 & 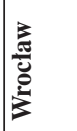 & 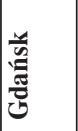 & 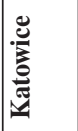 & 羿 & 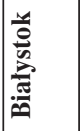 & 罭 \\
\hline Pieczywo ( w kg) & 4,76 & 4,51 & 4,60 & 4,59 & 4,63 & 4,61 & 4,59 & 5,03 & 5,26 & 5,25 & 4,59 \\
\hline Mąka (w kg) & 1,08 & 1,02 & 1,08 & 1,09 & 1,05 & 1,07 & 1,06 & 1,09 & 1,10 & 1,14 & 1,06 \\
\hline Kasze i płatki (w kg) & 0,48 & 0,51 & 0,48 & 0,42 & 0,62 & 0,49 & 0,49 & 0,47 & 0,46 & 0,43 & 0,44 \\
\hline Makaron (w kg) & 0,46 & 0,45 & 0,47 & 0,46 & 0,48 & 0,44 & 0,47 & 0,45 & 0,47 & 0,47 & 0,45 \\
\hline Ryż (w kg) & 0,25 & 0,29 & 0,26 & 0,21 & 0,25 & 0,27 & 0,26 & 0,29 & 0,28 & 0,21 & 0,23 \\
\hline Warzywa (w tym ziemn & 12,12 & 12,59 & 12,11 & 11,96 & 12,03 & 12,14 & 12,06 & 11,59 & 12,61 & 12,36 & 11,72 \\
\hline Owoce (w kg) & 4,83 & 5,18 & 4,93 & 4,26 & 4,86 & 4,90 & 4,91 & 4,38 & 4,99 & 4,97 & 4,89 \\
\hline Mięso (w kg) & 6,96 & 5,96 & 6,75 & 7,43 & 7,28 & 6,96 & 7,31 & 7.98 & 6,26 & 6,59 & 7,09 \\
\hline Ryby (w kg) & 0,52 & 0,67 & 0,62 & 0,42 & 0,52 & 0,59 & 0,65 & 0,46 & 0,44 & 0,36 & 0,46 \\
\hline $\begin{array}{l}\text { Margaryna i pozostałe tłuszcze } \\
\text { roślinne (w kg) }\end{array}$ & 1,12 & 1,16 & 1,09 & 1,23 & 1,14 & 1,05 & 1,09 & 1,12 & 1,13 & 1,08 & 1,10 \\
\hline Mleko (w l) & 4,03 & 4,06 & 3,99 & 4,32 & 4,11 & 3,57 & 3,96 & 4,01 & 4,08 & 4,19 & 3,99 \\
\hline Jogurty i napoje mleczne (w l) & 0,60 & 0,73 & 0,67 & 0,56 & 0,63 & 0,71 & 0,68 & 0,42 & 0,52 & 0,54 & 0,66 \\
\hline Sery twarogowe (w kg) & 0,62 & 0,71 & 0,66 & 0,54 & 0,58 & 0,63 & 0,70 & 0,61 & 0,54 & 0,52 & 0,66 \\
\hline Sery dojrzewające i topione (w kg) & 0,41 & 0,53 & 0,42 & 0,33 & 0,41 & 0,43 & 0,45 & 0,37 & 0,39 & 0,35 & 0,40 \\
\hline Tłuszcze zwierzęce (w kg) & 0,60 & 0,51 & 0,54 & 0,56 & 0,71 & 0,62 & 0,58 & 0,61 & 0,66 & 0,64 & 0,59 \\
\hline Jaja (w szt.) & 15,99 & 16,73 & 15,46 & 15,23 & 16,03 & 15,57 & 14,96 & 15,83 & 16,98 & 17,02 & 16,06 \\
\hline Herbata (w kg) & 0,09 & 0,09 & 0,08 & 0,09 & 0,09 & 0,09 & 0,10 & 0,08 & 0,09 & 0,11 & 0,09 \\
\hline Kawa (w kg) & 0,30 & 0,26 & 0,26 & 0,21 & 0,23 & 0,25 & 0,27 & 0,24 & 0,22 & 0,19 & 0,20 \\
\hline Cukier (w kg) & 1,66 & 1,58 & 1,64 & 1,79 & 1,60 & 1,72 & 1,68 & 1,64 & 1,73 & 1,69 & 1,58 \\
\hline Wody mineralne i źródlane (w l) & 4,58 & 5,06 & 4,96 & 4,36 & 4,58 & 4,61 & 4,63 & 4,52 & 4,36 & 4,29 & 4,39 \\
\hline Soki owocowe i warzywne (w l) & 0,71 & 0,96 & 0,79 & 0,53 & 0,76 & 0,74 & 0,72 & 0,69 & 0,75 & 0,49 & 0,71 \\
\hline
\end{tabular}

Źródło: badania własne.

W gospodarstwach domowych seniorów osiągających miesięczne dochody per capita powyżej 4000,00 zł, w porównaniu $\mathrm{z}$ rodzinami o najniższych dochodach (do 2000,00 zł na 1 osobę) spożywano ponad trzykrotnie więcej soków owocowych i warzywnych, jogurtów i napojów mlecznych, prawie dwuipółkrotnie więcej ryb oraz warzyw i prawie dwukrotnie więcej owoców. Natomiast w gospodarstwach seniorów o najniższych dochodach spożywano więcej pieczywa, mąki, ziemniaków i cukru. Ponadto, bez względu na poziom zamożności gospodarstw domowych, ponad 1/3 seniorów twierdziła, że sukcesywnie rezygnuje ze spożycia tłuszczów zwierzęcych, w tym masła, na rzecz tłuszczów roślinnych. Takie postępowanie badanych jest niewątpliwie przejawem zmian we wzorcach wyżywienia, polegających na coraz częstszym odchodzeniu od spożywania tłuszczów zwierzęcych na korzyść tych, które nie zawierają groźnego dla organizmu człowieka cholesterolu.

Odnotowano także, że słuchacze UTW częściej niż seniorzy uczestniczący we wspólnotach parafialnych spożywali kasze i płatki, warzywa i owoce, jogurty i napoje mleczne, ryby oraz soki owocowe i warzywne, natomiast mniej pieczywa, tłuszczów zwierzęcych, jaj, mleka i ziemniaków.

Spożycie żywności jest skorelowane z miejscem zamieszkania. Utrzymują się różnice w modelu spożycia artykułów żywnościowych pomiędzy poszczególnymi miastami. Pieczywa i produktów zbożowych 
na osobę najwięcej spożywali mieszkańcy Lublina $(5,26 \mathrm{~kg})$ i Białegostoku $(5,25 \mathrm{~kg})$, a najmniej Gdańska $(4,59 \mathrm{~kg})$ i Torunia $(4,59 \mathrm{~kg})$. Kasz i płatków na osobę najwięcej spożywali seniorzy mieszkający w Poznaniu $(0,62 \mathrm{~kg})$, zaś najmniej osoby w wieku $65+$ mieszkające w Łodzi $(0,42 \mathrm{~kg})$. Najwięcej mięsa i przetworów mięsnych na osobę spożywano w Katowicach $(7,98 \mathrm{~kg})$, a najmnie w Warszawie $(5,96 \mathrm{~kg})$. Z kolei najwięce mleka na osobę spożywano w Lodzi $(4,321)$, zaś najmniej we Wrocławiu (3,57 1). Jogurtów i napojów mlecznych na osobę najwięcej spożywali seniorzy mieszkający w Warszawie (0,73 1), zaś najmniej pochodzący z Katowic (0,42 1). Natomiast najwięcej ryb na osobę spożywali seniorzy zamieszkujący Warszawę $(0,67 \mathrm{~kg})$, a najmniej pochodzący z Lublina $(0,36 \mathrm{~kg})$.

Najwyższe spożycie na osobe owoców odnotowano w Warszawie $(5,18 \mathrm{~kg})$, a najniższe w Łodzi (4,26 kg). Warzyw najwięcej spożywali seniorzy zamieszkujący Lublin $(12,61 \mathrm{~kg})$, a najmniej mieszkajacy w Toruniu $(11,72 \mathrm{~kg})$. Jeśli zaś chodzi o soki owocowe i warzywne, to najwięcej na osobę spożywali ich seniorzy mieszkający w Warszawie $(0,961)$, najmniej zaś zamieszkujący Białystok (0,49 1).

W kontekście przeprowadzonego badania można wnioskować, że przeciętne miesięczne spożycie wybranych produktów żywnościowych nie jest wyrazem zadowalającego poziomu życia badanych gospodarstw domowych, lecz raczej konsekwencją konieczności przeznaczania większych sum na inne cele, głównie utrzymanie mieszkania. Dotyczy to zwłaszcza gospodarstw miejskich, uzależnionych w tych opłatach od polityki państwa. Należy w tym miejscu zaznaczyć, że przeprowadzona analiza przeciętnego miesięcznego spożycia produktów żywnościowych na 1 osobe nie pozwala na wyciągnięcie jednoznacznych wniosków co do wzorca ich spożycia w poszczególnych miastach.

Jak pokazują wyniki przeprowadzonego badania, wśród wielu determinant wpływających na wybór produktów żywnościowych istotną rolę odgrywają uwarunkowania ekonomiczne (przede wszystkim cena produktu). Na cene, jako determinant decydujący o zakupie określonego produktu żywnościowego, wskazało ponad 3/5 seniorów. Z kolei co drugi badany twierdzit, że istotnym uwarunkowaniem związanym bezpośrednio $\mathrm{z}$ atrybutami produktów żyw- nościowych jest świeżość oraz cechy sensoryczne: wygląd, wartości odżywcze, cechy zwiększające funkcjonalność i ułatwiające przygotowanie posiłków. Natomiast zdaniem co trzeciego seniora istotnym czynnikiem przesądzającym o zakupie produktów żywnościowych są determinanty indywidualne, tj. przyzwyczajenie czy postrzeganie marki producenta.

Jeśli zaś chodzi o płeć, to zgodnie z tradycyjnym podziałem ról odgrywanych w polskiej rodzinie $\mathrm{w}$ procesie zakupu, kobiety w większym stopniu są nabywcami dóbr żywnościowych. Przeszło $3 / 5$ badanych było zdania, że decyzje o zakupie żywności podejmowane są w ich gospodarstwach domowych przez kobiety. Jedynie co piąty senior twierdził, że decyzje o zakupie żywności mają charakter decyzji wspólnej.

\section{Podsumowanie}

Kluczową cechą preferencji konsumpcyjnych gospodarstw domowych osób w starszym wieku, a w efekcie i modelu konsumpcji, jest ich wyposażenie w dobra trwałego użytku, które tworzą tzw. infrastrukturę domową. W zachowaniach konsumenckich, oprócz nabywania i użytkowania dóbr trwałego użytku, duże znaczenie odgrywa samo ich posiadanie. Gospodarstwa domowe seniorów są najlepiej wyposażone w pralki, chłodziarki/zamrażarki, odbiorniki telewizyjne, telefony komórkowe i odkurzacze elektryczne, najsłabiej zaś w - kuchenki elektryczne z płytą ceramiczną, odtwarzacze MP3, kamery wideo, zestaw kina domowego oraz jednoślady (motocykl/motorower).

$\mathrm{Z}$ obserwacji zmian poziomu wyposażenia gospodarstw domowych seniorów wynika jednoznacznie, że poprawa wyposażenia ma charakter nie tylko ilościowy, ale przede wszystkim jakościowy. Zaobserwować można wyraźny wzrost wyposażenia w dobra teleinformatyczne, które świadczą o unowocześnieniu wzorców konsumpcji.

W przypadku artykułów żywnościowych poziom ich spożycia zależy w dużej mierze od dochodów seniorów. W najzamożniejszych gospodarstwach seniorów, w porównaniu $\mathrm{z}$ rodzinami o najniższych dochodach, spożywa się więcej soków owocowych i warzywnych, jogurtów i napojów mlecznych, ryb, oraz warzyw i owoców. Natomiast 
w gospodarstwach o najniższych dochodach kupuje się więcej pieczywa, mąki, ziemniaków i cukru. Ponadto, bez względu na poziom zamożności w ponad 30\% gospodarstw seniorów tłuszcze zwierzęce, w tym masło, są sukcesywnie zastępowane przez tłuszcze roślinne. Takie postępowanie osób w wieku $65+$ jest przejawem dbania o swoje zdrowie i ograniczanie spożywania groźnego dla organizmu człowieka cholesterolu.

\section{Przypisy}

1 W literaturze anglosaskiej stosuje sie podzia osób starszych na trzy grupy: 1) młodzi starzy (young old) - osoby w wieku 60/65-74 lata, 2) starzy starzy (old old) - w wieku 75-84 lata i 3) najstarsi starzy (the oldest old) - osoby w wieku 85 lat i więcej. Przyjęty w badaniu podział wieku starszego jest zbliżony do podziału zaproponowanego przez WHO. Autor badania przyjął podział wieku starszego na: 1) wiek podeszły, do którego zaliczaja sie osoby między 65. a 74. rokiem życia, 2) wiek starczy, gdzie kwalifikują się osoby między 75. a 84 rokiem życia, oraz 3) wiek sędziwy, do którego należą osoby powyżej 85. roku życia. Według ONZ za umowny poczatek starości uważa się 65. rok życia. Należy jednak pamiętać, że starość nie wiąże się jedynie z liczbą lat, którą dana osoba przeżyła. Odróżniamy wiek kalendarzowy (chronologiczny, metrykalny) i wiek biologiczny. Wpływ wielu czynników powoduje niejednokrotnie bardzo duże rozbieżności między wiekiem kalendarzowym a wiekiem biologicznym.

\section{Bibliografia}

Alderfer, C.P. (1972). Existence, relatedness and growth. New York: Free Press.

Gutkowska, K., Ozimek, I. i Laskowski, W. (2001). Uwarunkowania konsumpcji $w$ polskich gospodarstwach domowych. Warszawa: Wydawnictwo SGGW.

Kędzior, Z. (1989). Domowe dobra trwałego użytku w procesie zaspokajania potrzeb gospodarstw domowych. Gospodarstwo Domowe, 1.
Kusińska, A. (2009). Zmiany w sferze konsumpcji i ich uwarunkowania w latach 1989-2009. Handel Wewnętrzny, 4-5.

McClellan, D.C. (1975). Power: the inner experience. New York: Halstead.

Maslow, A.H. (1954). Motivation and Personality. New York: Harper and Row.

Max-Neef, M. (1991). Human Scale Development. Conception, Application and Further Reflection. New York-London: Apex Press,.

Pronovost, G. (2007). L'univers du temps libre et des valeures chez les jeunes. Quebec: Presses de l'Universite du Quebec.

Słaby, T. (red.). (2006). Elity ekonomiczne w Polsceujęcie empiryczne. Warszawa: Oficyna Wydawnicza $\mathrm{SGH}$.

Wątorski, J. (1987). Mieszkanie i domowe dobra trwate $w$ konsumpcji rodzin miejskich. Wrocław: Wydawnictwo Akademii Ekonomicznej we Wrocławiu.

Zalega, T. (2008). Konsumpcja $w$ gospodarstwach domowych o niepewnych dochodach. Warszawa: Wydawnictwo Naukowe Uniwersytetu Warszawskiego.

Zalega, T. (2009). Modele zachowań konsumentów w teoriach ekonomicznych i marketingowych. $M B A, 1(96)$.

Zalega, T. (2010a). Uwarunkowania zaspokojenia potrzeb w zakresie mieszkania i jego wyposażenia w gospodarstwach domowych wysokodochodowych. $M B A, 4(105)$.

Zalega, T. (2010b). Konsumpcja $w$ wielkomiejskich gospodarstwach domowych $w$ Polsce $w$ okresie kryzysu finansowo-ekonomicznego. Warszawa: Wydawnictwo Naukowe Wydziału Zarządzania Uniwersytetu Warszawskiego.

Zalega, T. (2011). Spożycie żywności w gospodarstwach domowych $\mathrm{z}$ osobami bezrobotnymi w województwie mazowieckim. Zeszyty Naukowe SGGW, 93

Zalega, T. (2012). Konsumpcja. Determinanty, teorie i modele. Warszawa: PWE.

Żelazna, K., Kowalczuk, I. i Mikuta, B. (2002). Ekonomika konsumpcji, elementy teorii. Warszawa: Wydawnictwo SGGW. 